\title{
Analysis of Survival of the Patients with Brain Metastases from Lung Cancer according to Treatment Modalities and Prognostic Indexes
}

\author{
(1) Halil SAĞINÇ,' (1) Papatya Bahar BALTALARLI² \\ 'Department of Radiation Oncology, Denizli State Hospital, Denizli-Turkey \\ ${ }^{2}$ Department of Radiation Oncology, Pamukkale University, Denizli-Turkey
}

\begin{abstract}
OBJECTIVE
This study aimed to retrospectively evaluate overall survival (OS) of the patients with brain metastases (BM) from lung cancer who had been treated with whole-brain radiotherapy (WBRT) and gamma knife (GK) according to prognostic factors and prognostic score indexes.
\end{abstract}

\section{METHODS}

Ninety-five patients with brain metastases from lung cancer were retrospectively evaluated using age, sex, lung cancer histological type, extracranial metastases, primary tumor control, number of brain metastases, total brain metastases volume, brain metastasectomy, chemotherapy, EGFR mutation, EGFR-TKI therapy, Karnofsky Performance Status (KPS), Recursive Partitioning Analysis (RPA) Class, Basic Score for Brain Metastases (BS-BM), Graded Prognostic Assessment Index (DS-GPA) and Modified Lung-Specific between 2015 and 2018. Univariate analysis of OS was performed using the Kaplan-Meier method supplemented by the log-rank test. We also applied multivariate survival analysis using the Cox Regression Model.

\section{RESULTS}

The median OS for all patients with brain metastases from lung cancer was six months \pm SE: 0.807 (range: 1-42 months; 95\% CI: 4.419-7.581) and one-year overall survival rate was $25.3 \%$. The median OS was four months, four months, 12 months in the WBRT arm, the GK arm and the combined WBRT-GK arm, respectively $(\mathrm{p}=0.004)$. In multivariate analysis, treatment with WBRT-GK $(\mathrm{p}=0.030)$, brain metastasectomy $(\mathrm{p}=0.019)$, controlled primary tumor $(\mathrm{p}=0.004)$, chemotherapy $(\mathrm{p}=0.001)$ were significantly correlated with overall survival. BS-BM $(\mathrm{p}=0.033)$ was closely related to overall survival compared to other prognostic score indexes on the multivariate analysis.

\section{CONCLUSION}

The patients with BM benefited from WBRT and GK combined therapy. BS-BM for the survival of patients with BM from lung cancer is the most appropriate prognostic index.

Keywords: Brain metastases; lung cancer; prognostic index; survival.

Copyright $\odot$ 2020, Turkish Society for Radiation Oncology

\section{Introduction}

Lung cancer is the most common source of brain metastases.[1] The aims of treatment are palliation of neurological symptoms, maintenance of performance status, and local control of the metastatic disease. [2] Whole-brain radiotherapy (WBRT) is commonly used to improve neurological symptoms in patients

\section{Dr. Halil SAĞINÇ}

Denizli Devlet Hastanesi,

Radyasyon Onkolojisi Kliniği,

Denizli-Turkey

E-mail: halilsaginc@hotmail.com 
with multiple brain metastases and control the disease within the brain.[1,3-6] Stereotactic radiosurgery is a good choice for oligometastatic brain lesions, $[5,7,8]$ and a metastasectomy is also a treatment option. However, the selection of local treatment only or WBRT depends on the performance of the patient, number of brain metastases, and histology.[9] In patients with oligo brain metastases treated with radiosurgery or metastasectomy, the addition of WBRT to the treatment regimen has reduced intracranial recurrence and neurological mortality. The most important problem in patients with the addition of WBRT is neurocognitive function failure. However, functional independence and mean survival were not improved.[10] WBRT and radiosurgery are decreased in learning and memory function compared to radiosurgery alone.[11] WBRT and radiosurgery improved control of local and remote brain metastases compared to the radiosurgery alone. [12] The potential benefit of GK radiosurgery is the reduction of radiation to the surrounding normal brain parenchyma, which may thereby reduce neurological toxicities compared with WBRT $[2,13]$ or which may improve local control when combined with WBRT.[5]

KPS score, primary lesion control, presence of extracranial metastases, presence of multiple metastases are important prognostic factors in the literature. $[9,14-$ 16] In recent years, several prognostic scoring systems based on independent prognostic factors have been developed to evaluate pretreatment variable contributions, to choose the appropriate treatment for individual patients, and guide future research. The most widely used indices are RPA class, BS-BM, and GPA.[14,15,16] The addition of brain tumor volume to the lung-specific GPA index (Modified Lung-Specific GPA) better predicted the OS of patients with brain metastasis from lung cancer.[17] Clinical parameters used for prognostic indexes (RPA, BSBM, DS-GPA, and Modified LungSpecific GPA) are shown in Table 1.

In this study, retrospective examination of the patients with brain metastases from lung cancer who were treated with WBRT, GK, and combined WBRTGK in a single center were reported. We tried to find out the appropriate prognostic indexes for all patients with BM who underwent GK, WBRT, and combined WBRT-GK.

\section{Materials and Methods}

\section{Study Design}

This study included 95 patients with brain metastases from lung cancer who underwent total WBRT, GK radiosurgery, or combined WBRT-GK between 2015 and 2018. Seventy patients with non-small-cell lung cancer and twenty-five patients with small-cell lung cancer were included in our study.

\section{Data Collection}

Data of 95 patients were retrospectively collected and evaluated regarding the clinical characteristics, including age, sex, WBRT treatment, GK treatment, histological type of lung cancer, extracranial metastases, primary tumor control, number of brain metastases, total brain metastases volume, brain metastasectomy, EGFR mutation, EGFR-TKI therapy, Karnofsky Performance Status (KPS), RPA Class, BS-BM, DS- GPA, and Modified Lung-Specific GPA. Prognostic indexes, such as RPA Class, BS-BM, DS-GP, Modified Lung-Specific GPA, were applied to patients with brain metastases. These criteria were chosen in accordance with previous studies that identified significant predictors of survival in patients with brain metastases. $[9,14,16-18]$

\section{Study Procedures WBRT}

Patients with multiple brain metastases were chosen for the treatment with WBRT. Patients were immobilised in a supine position within a thermoplastic mask. The brain was contoured as a clinical target volume (CTV) until the foramen magnum. The CTV was equal to the PTV. All BM, optic nerves, brainstem, eyes and lenses were contoured. Patients were positioned with a mask. The use of a planning CT was mandatory with a slice thickness of $\leq 5 \mathrm{~mm}$. WBRT was performed with 6-MV photons from a Siemens Artiste linear accelerator. The daily prescription dose is 2.5 and 3 Gy prescribed at the ICRU reference point.

\section{Study Procedures Radiosurgery}

The patients with $<3 \mathrm{~cm}$ and 1-3 brain metastases were chosen for treatment with gamma knife. Patients were immobilised in a supine position with a stereotactic fixation system using an invasive frame. A planning CT scan with $\leq 2 \mathrm{~mm}$ thick contiguous slices (preferable CT slice thickness $=1 \mathrm{~mm}$ ) will be fused to a contrastenhanced stereotactic MRI scan. BMs were contoured as a CTV to PTV margin used. Radiosurgery was performed with Elekta Leksell GK machine. Doses ranged from 15 to $25 \mathrm{~Gy}$.

\section{Patient Follow Up, Salvage Therapy}

The metastatic brain lesions of the patients in this study were followed by magnetic resonance imaging (MRI). OS was referenced from the day the diagnosis of brain 
Table 1 Clinical parameters used for prognostic indexes (RPA, DS-GPA, and BS-BM)

RPA

\begin{tabular}{|c|c|c|c|}
\hline \multicolumn{4}{|c|}{ Age $<65$ y, KPS $\geq 70$, controlled primary tumor, no extracranial metastases } \\
\hline \multicolumn{4}{|c|}{ All patients not in Class 1 or 3} \\
\hline \multirow[t]{3}{*}{ Class 3} & $\mathrm{KPS}<70$ & & \\
\hline & \multicolumn{3}{|c|}{ DS-GPA } \\
\hline & 0 & 0.5 & 1 \\
\hline Age,year & $>60$ & $50-59$ & $<50$ \\
\hline KPS & $<70$ & $70-80$ & $90-100$ \\
\hline Number of BM & $>3$ & $2-3$ & 1 \\
\hline \multirow[t]{3}{*}{ ECM } & Yes & & \\
\hline & \multicolumn{3}{|c|}{ BS-BM } \\
\hline & 0 & 1 & \\
\hline KPS & $50-70$ & $80-100$ & \\
\hline Control of primary tumor & No & Yes & \\
\hline \multirow[t]{3}{*}{ ECM } & Yes & No & \\
\hline & \multicolumn{3}{|c|}{ Modified lung-Specific GPA } \\
\hline & 0 & 0.4 & 0.8 \\
\hline Age, year & $>60$ & $50-59$ & $<50$ \\
\hline KPS & $<70$ & $70-80$ & $90-100$ \\
\hline Number of BM & $>3$ & $2-3$ & 1 \\
\hline ECM & Yes & No & \\
\hline Total brain metastases volume & $>4 \mathrm{~cm}^{3}$ & $\leq 4 \mathrm{~cm}^{3}$ & \\
\hline
\end{tabular}

KPS: Karnofsky Performance Status; RPA: Recursive partitioning analysis; BS-BM: Basic score for brain metastases, DS-GPA: Diseases specific-graded prognostic assessment; BM: Brain metastases; ECM: Extracranial metastases

metastases was confirmed by MRI. Intracerebral failure was diagnosed with MRI. The exact frequency and number of MRIs following irradiation were unavailable because the anonymized database used did not include these data. In general, the follow-up schedule after therapy included MRI every three months, whereas MRI was performed only in cases of new or progressive symptoms in most patients undergoing WBRT or GK. All patients with brain metastases from lung cancer were treated after being evaluated by the Neurosurgery and Radiation Oncology Departments. Salvage SRS (stereotactic radio-surgery) was added to a treatment option for recurrent BM after the failure of WBRT.[19] After SRS, salvage WBRT was added to reduce intracranial relapses and neurologic deaths.[20] Patients who underwent only Gamma Knife treatment, only WBRT treatment, salvage treatment accepted in GK arm, in WBRT arm, in the combine treatment arm (WBRT-GK arm), respectively. We accepted patients who underwent salvage treatment due to progression after WBRT treatment or SRS treatment combined WBRT-GK arm.

\section{Statistical Analysis}

Univariate analysis of OS was performed using the Kaplan-Meier method supplemented by the log-rank test to find out the factors.[21] We also applied multivariate survival analysis using the Cox Regression Model. Only the factors that exhibited statistical significance in univariate analysis were included in a multivariate analysis that utilized Cox proportional hazards regression tests. All tests were two-tailed, and a p-value $<0.05$ was considered significant. The statistical analyses were reviewed by medical statistician staff in our medical faculty.

\section{Results}

\section{Patients Characteristics}

This study included 95 patients with brain metastases from lung cancer. Of 95 patients, $70(73.7 \%)$ and 25 (26.3\%) had non-small-cell cancer and small-cell ca, respectively. Of 95 patients, 28 (29.4\%), 36 (37.9\%), 6 (6.4\%) and 25 (26.3\%) had squamous cell ca, adeno ca, nsclc (other type) and small-cell ca, respectively. 
Table 2 Clinical characteristics and results of the univariate analysis (Kaplan-Meier, log-rank test) of OS of patients with brain metastasis from lung cancer

\begin{tabular}{|c|c|c|c|c|}
\hline \multirow[t]{2}{*}{ Clinical characteristics $(n=95)$} & \multirow[t]{2}{*}{ Number of patients (\%) } & \multirow[t]{2}{*}{$\operatorname{Ex}(n=83)$} & \multicolumn{2}{|l|}{ Log-Rank Test } \\
\hline & & & Median OS \pm SE $95 \% \mathrm{Cl}$ & p-value \\
\hline Age $>60$ years & $48(50.5)$ & 44 & 5 months $\pm 1.155 \mathrm{Cl}: 2.737-7.263$ & $p>0.05$ \\
\hline$\leq 60$ years & $47(49.5)$ & 39 & 6 months $\pm 0.753 \mathrm{Cl}: 4.524-7.476$ & \\
\hline Male & 89 (93.7) & 78 & 5 months $\pm 0.858 \mathrm{Cl}: 3.319-6.681$ & $p>0.05$ \\
\hline Female & $6(6.3)$ & 5 & 8 months $\pm 3.062 \mathrm{Cl}: 1.999-14.001$ & \\
\hline Non-small cell lung cancer & $70(73.7)$ & 61 & 5 months $\pm 0.930 \mathrm{Cl}: 3.178-6.822$ & $p>0.05$ \\
\hline Small cell lung cancer & $25(26.3)$ & 22 & 6 months $\pm 1.665 \mathrm{Cl}: 2.736-9.264$ & \\
\hline Nsclc (squamous cell ca) & $28(29.4)$ & 26 & 4 months $\pm 0.880 \mathrm{Cl}: 2.276-5.724$ & $p>0.05$ \\
\hline Nsclc (adeno ca) & $36(37.9)$ & 29 & 11 months $\pm 2.958 \mathrm{Cl}: 5.202-16.798$ & \\
\hline Nsclc (other thype) & $6(6.4)$ & 6 & 4 months $\pm 0.577 \mathrm{Cl}: 2.868-5.132$ & \\
\hline Small cell ca & $25(26.3)$ & 22 & 6 months $\pm 1.165 \mathrm{Cl}: 2.736-9.264$ & \\
\hline Radiotherapy (WBRT) & $27(28.1)$ & 26 & 4 months $\pm 0.645 \mathrm{Cl}: 2.735-5.265$ & $p=0.004$ \\
\hline Radiosurgery (GK) & $39(40.6)$ & 34 & 4 months $\pm 0.694 \mathrm{Cl}: 2.640-5.360$ & \\
\hline WBRT-GK)(combined) & $29(30.2)$ & 23 & 12 months $\pm 2.4783 \mathrm{Cl}: 7.134-16.866$ & \\
\hline Brain metastasectomy & $35(36.8)$ & 26 & 12 months $\pm 3.513 \mathrm{Cl}: 5.114-18.886$ & $p=0.004$ \\
\hline No brain metastasectomy & $60(63.2)$ & 57 & 4 months $\pm 0.644 \mathrm{Cl}: 2.738-5.262$ & \\
\hline Controlled primary tumor & $20(21.1)$ & 15 & 20 months $\pm 5.485 \mathrm{Cl}: 9.249-30.751$ & $p=0.000$ \\
\hline Uncontrolled primary tumor & $75(78.9)$ & 68 & 4 months $\pm 0.666 \mathrm{Cl}: 2.695-5.305$ & \\
\hline No extracranial metastases & $24(25.3)$ & 20 & 12 months $\pm 2.276 \mathrm{Cl}: 7.539-16.461$ & $p=0.035$ \\
\hline Extracranial metastases & $71(74.7)$ & 63 & 4 months $\pm 0.702 \mathrm{Cl}: 2.625-5.375$ & \\
\hline $1-2$ brain metastases & $51(53.7)$ & 43 & 6 months $\pm 0.884 \mathrm{Cl}: 4.267-7.733$ & $p>0.05$ \\
\hline 3-4 brain metastases & $26(27.4)$ & 22 & 7 months $\pm 1.700 \mathrm{Cl}: 3.669-10.331$ & \\
\hline$\geq 5$ brain metastases & $18(18.9)$ & 18 & 4 months $\pm 0.517 \mathrm{Cl}: 2.987-5.013$ & \\
\hline TBMV $>4 \mathrm{~cm} 3$ & $78(82.1)$ & 67 & 5 months $\pm 0.803 \mathrm{Cl}: 3.426-6.574$ & $p>0.05$ \\
\hline $\mathrm{TBMV} \leq 4 \mathrm{~cm} 3$ & $17(17.7)$ & 16 & 8 months $\pm 2.572 \mathrm{Cl}: 2.958-13.042$ & \\
\hline Chemotherapy & $79(83.2)$ & 68 & 7 months $\pm 1.111 \mathrm{Cl}: 4.823-9.177$ & $p=0.002$ \\
\hline No chemotherapy & $16(16.8)$ & 15 & 3 months $\pm 0.667 \mathrm{Cl}: 1.693-4.307$ & \\
\hline EGFR mutation positive (adenocarcinoma) & $11(11.7)$ & 9 & 6 months $\pm 1.101 \mathrm{Cl}: 3.842-8.158$ & $p>0.05$ \\
\hline EGFR mutation-negative and other type & $83(88.3)$ & 73 & 5 months $\pm 0.719 \mathrm{Cl}: 3.590-6.410$ & \\
\hline EGFR-TKI therapy & $10(10.6)$ & 8 & 6 months $\pm 1.581 \mathrm{Cl}: 2.901-9.099$ & $p>0.05$ \\
\hline No EGFR-TKI therapy & $25(26.6)$ & 21 & 11 months $\pm 3.062 \mathrm{Cl}: 4.999-17.001$ & \\
\hline No adenocarcinoma type & $59(62.8)$ & 53 & 5 months $\pm 0.636 \mathrm{Cl}: 3.754-6.246$ & \\
\hline$K P S \geq 70$ & $54(56.8)$ & 46 & 8 months $\pm 1.224 \mathrm{Cl}: 5.601-10.399$ & $p=0.005$ \\
\hline $\mathrm{KPS} \leq 60$ & $41(43.2)$ & 37 & 4 months $\pm 0.771 \mathrm{Cl}: 2.489-5.511$ & \\
\hline RPA Class 1 & $8(8.4)$ & 6 & 20 months $\pm 6.685 \mathrm{Cl}: 6.898-33.102$ & $p=0.003$ \\
\hline RPA Class 2 & $46(48.4)$ & 40 & 8 months $\pm 1.448 \mathrm{Cl}: 5.162-10.838$ & \\
\hline RPA Class 3 & $41(43.2)$ & 37 & 4 months $\pm 0.675 \mathrm{Cl}: 2.677-5.323$ & \\
\hline BS-BM 0 & $35(36.8)$ & 32 & 3 months $\pm 0.520 \mathrm{Cl}: 1.981-4.019$ & $p=0.001$ \\
\hline BS-BM 1 & $33(34.7)$ & 30 & 7 months $\pm 1.077 \mathrm{Cl}: 4.890-9.110$ & \\
\hline BS-BM 2 & $16(16.8)$ & 12 & 12 months $\pm 4.507 \mathrm{Cl}: 3.166-20.834$ & \\
\hline BS-BM 3 & $11(11.6)$ & 9 & 20 months $\pm 6.621 \mathrm{Cl}: 7.024-32.976$ & \\
\hline DS-GPA 0-1 & $34(35.8)$ & 29 & 4 months $\pm 1.093 \mathrm{Cl}: 1.857-6.143$ & $p=0.057$ \\
\hline DS-GPA 1.5-2.5 & $48(50.5)$ & 44 & 5 months $\pm 0.990 \mathrm{Cl}: 3.060-6.940$ & \\
\hline DS-GPA 3 and DS-GPA 3.5-4 & $13(13.7)$ & 10 & 12 months $\pm 6.419 \mathrm{Cl}: 0.000-24.582$ & \\
\hline Modified Lung-Specific GPA $\leq 1$ & $42(44.2)$ & 38 & 4 months $\pm 0.621 \mathrm{Cl}: 2.783-5.217$ & $p=0.027$ \\
\hline Modified Lung-Specific $1<\mathrm{GPA} \leq 2$ & $34(35.8)$ & 29 & 7 months $\pm 1.249 \mathrm{Cl}: 4.551-9.449$ & \\
\hline Modified Lung-Specific $2<\mathrm{GPA} \leq 3 \&>3$ & $19(20.0)$ & 16 & 12 months $\pm 2.902 \mathrm{Cl}: 6.312-17.688$ & \\
\hline Median survival $(\mathrm{n}=95)$ & 6 months \pm SE: 0.8 & ge: $1-4$ & months; 95\% Cl: 4.419-7.581) & \\
\hline
\end{tabular}

WBRT: Whole brain radiotherapy; GK: Gamma knife; KPS: Karnofsky Performance Status; RPA; Recursive partitioning analysis; BS-BM: The basic score for brain metastases; DS-GPA: Diseases specific-graded prognostic assessment; EGFR-TKI: The epidermal growth factor receptor-tyrosine kinase inhibitor; OS: Overall survival; TBMV: Total brain metastases volume; SE: Standard error; Cl: Confidence interval 
Among these patients, 89 (93.7\%) and six (6.3\%) were men and women, respectively. The median age was 61 years (min: 37 years, max: 83 years). The number of patients underwent WBRT, GK radiosurgery, and combined WBRT-GK was 27 (28.1\%), 39 (40.6\%), and $29(30.2 \%)$, respectively. In our study, 83 of 95 patients died during the study period. The median OS for all patients with brain metastases from lung cancer was six months \pm SE: 0.807 (range: 1-42 months; 95\% CI: 4.419-7.581) and one-year overall survival rate was $25.3 \%$.

\section{Survival Analysis}

In univariate analysis (Kaplan-Meier, log-rank test), the median OS of patients with brain metastases from lung cancer was significantly associated with treatment combined WBRT-GK, the presence of brain metastasectomy controlled primary tumor, the absence of extracranial metastases, chemotherapy, KPS score, RPA class, BS-BM, and Modified Lung-Specific GPA $(\mathrm{p}<0.05)$. The median OS of patients with brain metastases from lung cancer was not statistically significant with the age, sex, histological type of lung cancer, number of brain metastases, the tumor volume of brain metastases, EGFR mutation state, EGFR-TKI therapy, DS-GPA ( $>0.05)$. Clinical characteristics and results of the univariate analysis of the OS of patients with brain metastasis from lung cancer are presented in Table 2. The median OS was four months, four months, 12 months in the WBRT arm, the GK arm, the WBRTGK arm, respectively ( $\mathrm{p}=0.004)$ (Fig. 1). In our study, 26 of the 35 patients who underwent surgery, 57 of the 60 patients who did not undergo surgery, died. The median OS was four months and 12 months in patients

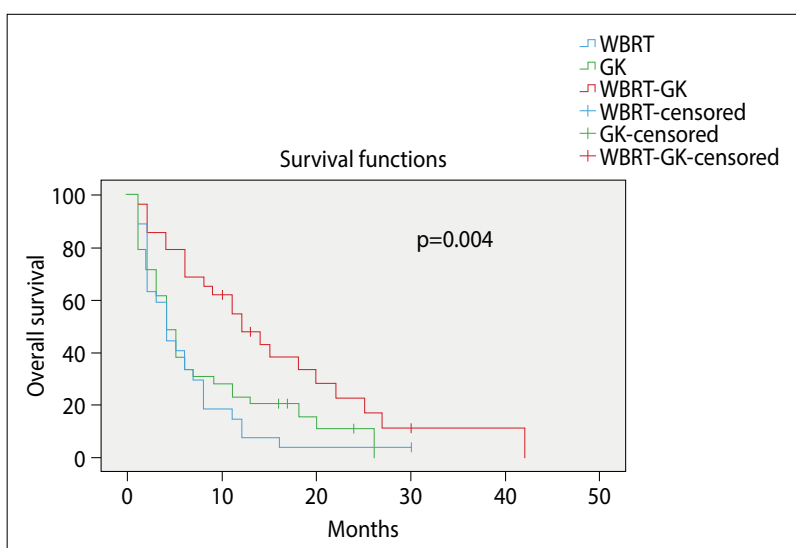

Fig. 1. Kaplan-Meier analysis of OS according to treatment arms. who did not undergo surgery and the patients who underwent surgery, respectively $(\mathrm{p}=0.004)$. The median OS was significantly associated with the controlled primary tumor and the absence of extracranial metastases $(\mathrm{p}<0.05)$. The median OS was four months, 20 months in the absence of primary tumor control, in the presence of primary tumor control, respectively $(p=0.000)$. The median OS was 12 months in patients without extracranial metastases, whereas the median OS was four months in patients with extracranial metastases $(p=0.035)$. The median OS was seven and three months in patients who received chemotherapy and who received no chemotherapy, respectively $(\mathrm{p}=0.002)$.

KPS, RPA class, BS-BM and Modified Lung-Specific GPA were all closely related to prognosis in our study on univariate anal $\neg$ ysis (Kaplan-Meier, log-rank test). The median OS was not statistically significant with DS-GPA (Fig. 2). The median OS was eight and four months in patients with KPS $\geq 70$ and lower KPS, respectively ( $\mathrm{p}=0.005)$. The median OS was 20 months, eight months, four months in patients with RPA Class 1, RPA Class 2, RPA Class 3, respectively ( $\mathrm{p}=0.003$ ). The median OS was three months, seven months, 12 months, 20 months in patients with BS-BM 0, BS-BM 1 , BS-BM 2, BS-BM 3 , respectively $(\mathrm{p}=0.001)$. The median OS was four months, six months, 12 months in patients with DS-GPA 0-1, DS-GPA 1.5-2.5, DS-GPA $3-3.5-4$, respectively $(\mathrm{p}=0.057)$. The median OS was four months, seven months, 12 months in patients with Modified Lung-Specific GPA $\leq 1$, Modified LungSpecific $1<\mathrm{GPA} \leq 2$, Modified Lung-Specific $2<\mathrm{GPA} \leq 3$ $\&>3$, respectively $(\mathrm{p}=0.027)$.

In univariate analysis, we found that patients with brain metastases from lung cancer with age $\leq 60$ years, small-cell ca, the absence of brain metastasectomy, controlled primary tumor, extracranial metastases, the brain metastases $\geq 5$, the total tumor volume $>4 \mathrm{~cm} 3$, receiving chemotherapy had better overall survival in the combined WBRT-GK treatment arm according to treatment modality arms. However, patients with KPS $\geq 70$, KPS $\leq 60$, RPA Class 2-3, BS-BM 0, BS-BM 1, DS-GPA 0-1, DS-GPA 1.5-2.5, Modified Lung GPA $\leq 1$ were significantly correlated with overall survival in the combined WBRT-GK treatment arm according to treatment modality arms on univariate analysis $(\mathrm{p}<0.05)$. Results of the univariate analysis (KaplanMeier, log-rank test) of overall survival of the prognostic factors in patients with brain metastasis from lung cancer to treatment modality arms are presented in Table 3. For patients with brain metastases from small cell ca, the median OS was four months, two month, 


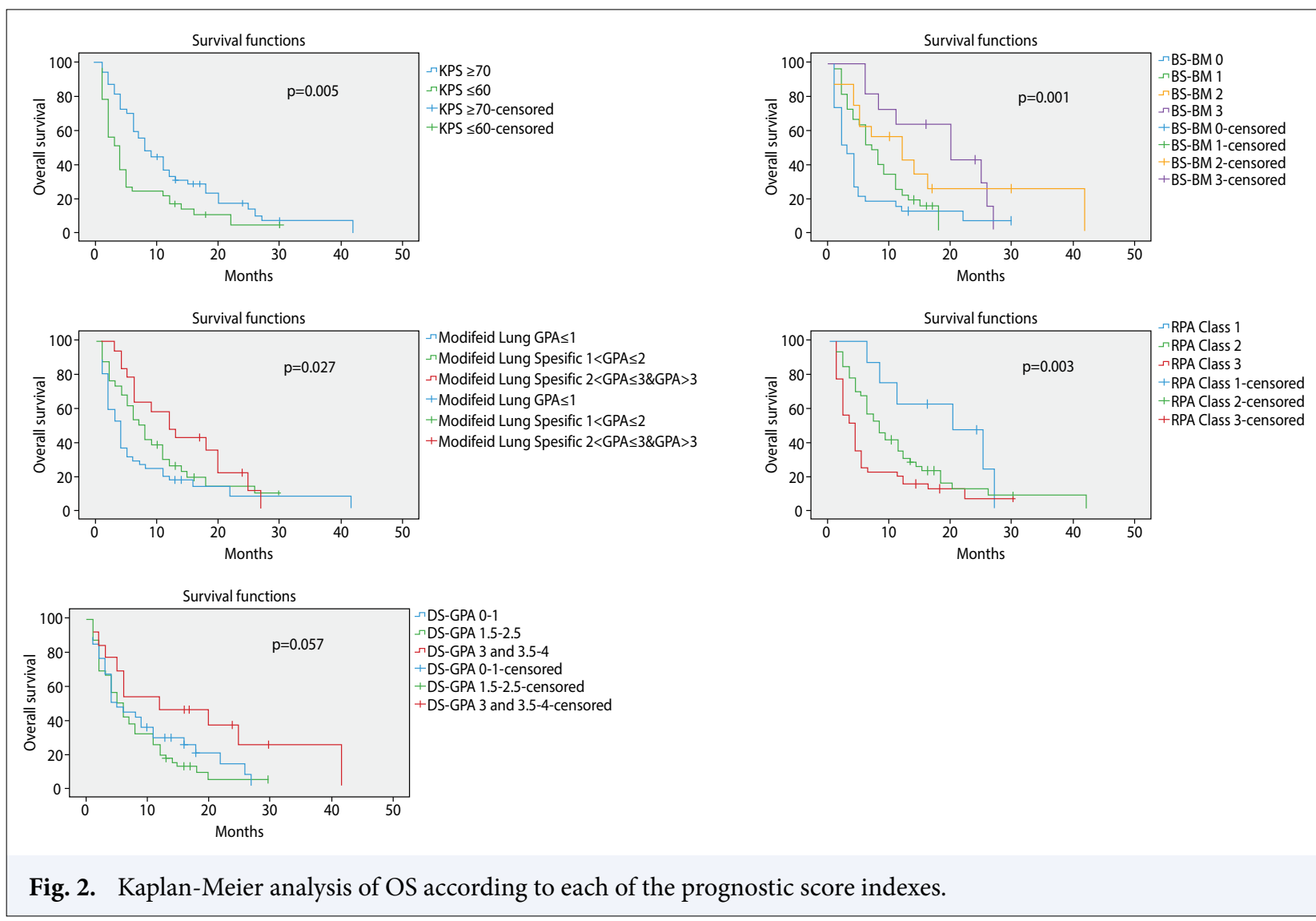

18 months in the WBRT, the GK arm, the combined WBRT-GK the treatment arm, respectively $(\mathrm{p}=0.000)$. The median OS was not statistically significant for patients with brain metastasectomy from non-smallcell according to the treatment arms ( $p>0.05)$. In the absence of brain metastasectomy, the median OS was four months in the WBRT arm and GK arm, and the median OS was eight months in the combined WBRTGK arm ( $p=0.026)$. The median OS was not statistically significant for patients who underwent brain metastasectomy according to the treatment arms ( $\mathrm{p}>0.05$ ). Patients with extracranial metastases had the highest median OS of 11 months in combined WBRT-GK arm $(\mathrm{p}=0.003)$. Patients with controlled primary tumor had the highest median OS of 27 months in combined WBRT-GK arm ( $\mathrm{p}=0.021)$. Among patients with oligo brain metastases, the median OS was not statistically significant according to the treatment modality arms ( $>0.05)$. For the patients with five or more brain metastases, the median OS was four months, one month in the WBRT, the GK arm, respectively, and 11 months in the combined WBRT-GK arm according to the treatment modality arms $(\mathrm{p}=0.014)$. The median OS was four months in the WBRT arm and GK arm, and the median OS was 12 months in the combined WBRT-GK arm for patients with brain metastases volume $>4 \mathrm{~cm} 3$, respectively $(\mathrm{p}=0.009)$. In patients receiving chemotherapy treatment, the combined WBRT-GK arm had higher median survival with 12 months than other treatment arms $(\mathrm{p}=0.032)$.

Patients with KPS $\geq 70$, KPS $\leq 60$, RPA Class $2-3$, BS-BM 0, BS-BM 1, DS-GPA 0-1, DS-GPA 1.5-2.5, Modified Lung GPA $\leq 1$ had the highest median overall survival in the combined WBRT-GK treatment arm according to treatment modality arms on univariate analysis $(\mathrm{p}<0.05)$.

The multivariate analysis demonstrated that treatment with WBRT-GK $(\mathrm{p}=0.030)$, brain metastasectomy $(\mathrm{p}=0.019)$, controlled primary tumor $(\mathrm{p}=0.004)$, chemotherapy treatment $(\mathrm{p}=0.001)$ were significantly correlated with overall survival. Results of the multivariate analysis (the Cox Regression Model) of the overall survival of the prognostic factors are presented in Table 4. In multivariate analysis, BS-BM ( $\mathrm{p}=0.033$ ) was closely related to the overall survival among the class of prognostic score indexes in our study. In multivariate analysis, BS-BM was a better predictor for the survival of patients with BM from lung cancer. However, KPS 
Table 3 Overall survival of the univariate analysis (Kaplan-Meier, log-rank test) of patients with brain metastases from lung cancer according to treatment modality arms

\begin{tabular}{|c|c|c|c|c|}
\hline Clinical characteristics $(n=95)$ & $\begin{array}{l}\text { WBRT treatment arm } \\
\text { Median OS months } \pm \text { SE } 95 \% \mathrm{Cl}\end{array}$ & $\begin{array}{c}\text { GK treatment arm } \\
\text { Median OS months } \pm \text { SE } 95 \% \mathrm{Cl}\end{array}$ & $\begin{array}{l}\text { WBRT-GK treatment arm } \\
\text { Median OS months } \pm \text { SE } 95 \% \mathrm{Cl}\end{array}$ & p-value \\
\hline Age $>60$ years & 4 months $\pm 1.541 \mathrm{Cl}: 0.980-7.020$ & 4 months $\pm 0.454 \mathrm{Cl}: 3.111-4.889$ & 12 months $\pm 5.555 \mathrm{Cl}: 1.1$ & 5 \\
\hline$\leq 60$ years & 4 months $\pm 0.617 \mathrm{Cl}: 2.790-5.210$ & 5 months \pm 1.379 Cl: $2.297-7.703$ & 15 months $\pm 3.352 \mathrm{Cl}: 8.429-21.571$ & $p=0.018$ \\
\hline Non-small cell lung cancer & 4 months $\pm 0.992 \mathrm{Cl}: 2.055-5.945$ & 5 months $\pm 0.725 \mathrm{Cl}: 3.580-6.420$ & 11 months $\pm 2.152 \mathrm{Cl}: 6.782-15.218$ & $p>0.05$ \\
\hline Small cell lung cancer & 4 months $\pm 1.651 \mathrm{Cl}: 0.763-7.237$ & 2 months $\pm 1.500 \mathrm{Cl}: 0.000-4.940$ & 18 months $\pm 4.985 \mathrm{Cl}: 8.229-27.771$ & $p=0.000$ \\
\hline Brain metastasectomy & Cl: 0.199-9.801 & 5 months $\pm 1.708 \mathrm{Cl}:$ & 15 months \pm & \\
\hline Controlled primary tumor & 8 months $\pm 5.000 \mathrm{Cl}: 0.000-17.800$ & 6 months $\pm 9.091 \mathrm{Cl}: 0.000-23.819$ & 27 months $\pm 3.947 \mathrm{Cl}: 19.265-34.735$ & $p=0.021$ \\
\hline Uncontrolled primary tumor & 4 months $\pm 0.585 \mathrm{Cl}: 2.853-5.147$ & 4 months $\pm 0.678 \mathrm{Cl}: 2.671-5.329$ & 11 months $\pm 2.156 \mathrm{Cl}: 6.774-15.226$ & $p>0.05$ \\
\hline No extracranial metastases & 11 months \pm 2.449 & 7 months \pm 6 & & \\
\hline Extracranial metastases & 4 months $\pm 0.949 \mathrm{Cl}: 2.141-5.859$ & 3 months $\pm 0.661 \mathrm{Cl}: 1.704-4.296$ & & \\
\hline $1-2$ brain metastasis & 4 months \pm 2 & 4 months $\pm 1.046 \mathrm{Cl}: 1.950-6.150$ & 12 months \pm & 5 \\
\hline $3-4$ brain metastasis & 4 months $\pm 1.414 \mathrm{Cl}: 1.228-6.772$ & 7 months $\pm 2.890 \mathrm{Cl}: 1.336-12.664$ & 15 months $\pm 7.205 \mathrm{Cl}: 0.879-29.121$ & $p>0.05$ \\
\hline$\geq 5$ brain metastases & 549 Cl: 0.964-7.036 & & 11 months $\pm 3.031 \mathrm{Cl}: 5$. & \\
\hline $\mathrm{TBMV} \leq 4 \mathrm{~cm} 3$ & 2 months & 6 months $\pm 3.953 \mathrm{Cl}: 0.0 \mathrm{C}$ & 9 months \pm & \\
\hline Chemotherapy & 6 months $\pm 2.225 \mathrm{Cl}: 1.639-10.361$ & 5 months $\pm 0.811 \mathrm{Cl}: 3.410-6.590$ & 12 months $\pm 2.283 \mathrm{Cl}: 7.525-16.475$ & $p=0.032$ \\
\hline No chemotherapy & 2 months \pm & 3 months \pm 1.225 & 4 months & $p>0.05$ \\
\hline $\mathrm{KPS} \geq 70$ & 4 months $\pm 2.806 \mathrm{Cl}: 0.000-9.500$ & 7 months $\pm 2.814 \mathrm{Cl}: 1.484-12.516$ & 12 months \pm & $p=0.001$ \\
\hline KPs & 4 months $\pm 1.169 \mathrm{Cl}: 1.708-6$ & 2 months $\pm 0.823 \mathrm{Cl}: 0.387-3.613$ & 12 months \pm 6 & $\mathrm{p}=0$ \\
\hline RPA Class 1 & 8 months & - & 25 months $\pm 4.082 \mathrm{Cl}: 16.998-33.002$ & $p>0.05$ \\
\hline RPA Class 2 & lonths $\pm 1.732 \mathrm{Cl}: 0.000-6.395$ & $82 \mathrm{Cl}: 0.76$ & 11 months $\pm 1.842 \mathrm{Cl}: 7.390-14.610$ & $p=0.001$ \\
\hline RPA Class 3 & 4 months $\pm 1.169 \mathrm{Cl}: 1.708-6.292$ & 2 months $\pm 0.849 \mathrm{Cl}: 0.337-3.663$ & 4 months $\pm 7.906 \mathrm{Cl}: 0.000-19.495$ & $p=0.021$ \\
\hline BS-BM 0 & 4 months $\pm 1.089 \mathrm{Cl}: 1.866-6.134$ & 2 months $\pm 0.661 \mathrm{Cl}: 0.704-3.296$ & 4 months $\pm 2.619 \mathrm{Cl}: 0.000-9.132$ & $p=0.054$ \\
\hline BS-BM 1 & 3 months $\pm 1.581 \mathrm{Cl}: 0.000-6.099$ & 6 months $\pm 3.464 \mathrm{Cl}: 0.000-12.790$ & 11 months $\pm 1.595 \mathrm{Cl}: 7.873-14.127$ & $p=0.006$ \\
\hline BS-BM 2 & 12 months $\pm 8.981 \mathrm{Cl}: 0.000-29.604$ & 5 months $\pm 0.577 \mathrm{Cl}: 3.868-6.132$ & 14 months $\pm 9.808 \mathrm{Cl}: 0.000-33.223$ & $p>0.05$ \\
\hline BS-BM 3 & 8 months & & 20 months $\pm 9.500 \mathrm{Cl}: 1.380-38.620$ & $p>0.05$ \\
\hline DS-GPA 0-1 & 11 months & thct 0639 Cl. 1748 & 9 months $\pm 6.062 \mathrm{Cl}: 0.000-20.882$ & $p=0.035$ \\
\hline DS-GPA 1.5-2.5 & 4 months $\pm 1.095 \mathrm{Cl}: 1.8$ & 5 months $\pm 0.926 \mathrm{Cl}: 3.185-6.815$ & 11 months $\pm 3.742 \mathrm{Cl}: 3.666-18.334$ & $p=0.011$ \\
\hline DS-GPA 3 and DS-C & 3 months $\pm 1.095 \mathrm{Cl}: 0.853-5.147$ & 20 months $\pm 11.142 \mathrm{Cl}: 0.000-41.837$ & 25 months $\pm 10.614 \mathrm{Cl}: 4.196-45.804$ & $p>0.05$ \\
\hline Modifeid Lung-Specific $2<$ GPA $\leq 3 \&>3$ & 12 months & 13 months $\pm 4.600 \mathrm{Cl}: 3.983-22.017$ & 12 months $\pm 3.928 \mathrm{Cl}: 4.301-19.699$ & $p>0.05$ \\
\hline
\end{tabular}

WBRT: Whole brain radiotherapy; GK: Gamma knife; KPS: Karnofsky Performance Status; OS: Overall survival; TBMV: Total brain metastases volume; RPA: Recursive partitioning analysis; BS-BM: Basic score for brain metastases; DS-GPA: Diseases specific-graded prognostic assessment; SE: Standard error; Cl: Confidence interval

score, RPA class, DS-GPA and Modified Lung-Specific GPA were not statistically significant with overall survival between patients with BM from lung cancer on multivariate analysis. Results of the multivariate analysis of overall survival according to prognostic score indexes are presented in Table 4.

\section{Discussion}

In our study, including 95 patients with brain metastases from lung cancer, the median OS was not statistically significant between patients with small-cell ca and nonsmall-cell ca ( $p>0.05)$. The median OS of patients with brain metastases from small-cell ca was four months, two months, 18 months in the WBRT, the GK arm, the combined WBRT-GK arm, respectively $(\mathrm{p}=0.000)$. A retrospective study by Wegner et al. suggested that pa- tients with SCLC who underwent a combined WBRT with radiosurgical boost had improved outcomes over patients who received either WBRT or SRS alone.[22] In our study, similar to the study of Wegner et al. combined radiotherapy and radiosurgery for small cell ca increases survival. In cases of wild-type EGFR and ALK NSCLC, there are few effective systemic options, and therefore, WBRT may have a more prominent role. Despite the current trend of preferring SRS alone, we need to carefully consider the important role of WBRT, particularly in patients with BM from NSCLC who have a favorable prognosis.[23] In our study, there was not statistically significance between OS of patients with EGFR mutation state, EGFR-TKI therapy.

In the study of Bowden, the presence of multiple brain metastases is a negative predictor of worse prognosis. [24] In other studies, the number of metastatic 
Table 4 Results of the multivariate analysis (Cox- regression test) of overall survival of the prognostic factors and prognostic score indexes of patients with brain metastases from lung cancer

Clinical characteristics $(\mathbf{n}=\mathbf{9 5})$

\section{Cox Regression \\ p-value HR $\quad 95 \% \mathrm{Cl}$}

$\mathrm{p}=0.065$

$\mathrm{p}=0.723 \mathrm{HR}: 0.907 \mathrm{Cl}: 0.529-1.555$

$\mathrm{p}=0.030 \mathrm{HR}: 0.518 \mathrm{Cl}: 0.286-0.937$

$p=0.019$ HR: $0.548 \mathrm{Cl}: 0.331-0.907$

$\mathrm{p}=0.004$ HR: $0.364 \mathrm{Cl}: 0.183-0.723$

$\mathrm{p}=0.895 \mathrm{HR}: 1.040 \mathrm{Cl}: 0.578-1.873$

$\mathrm{p}=0.001 \mathrm{HR}: 0.370 \mathrm{Cl}: 0.201-0.683$

$\mathrm{p}=0.964$ HR: $1.036 \mathrm{Cl}: 0.221-4.862$

$\mathrm{p}=0.642$ HR: $0.687 \mathrm{Cl}: 0.141-3.339$

$\mathrm{p}=0.033 \mathrm{HR}: 0.528 \mathrm{Cl}: 0.294-0.949$

$p=0.297$ HR: $0.641 \mathrm{Cl}: 0.278-1.479$

$p=0.447$ HR: $0.778 \mathrm{Cl}: 0.407-1.486$

WBRT: Whole brain radiotherapy; GK: Gamma knife; KPS: Karnofsky Performance Status; RPA: Recursive partitioning analysis; BS-BM: Basic score for brain metastases; DS-GPA: Diseases specific-graded prognostic assessment; OS: Overall survival; SE: Standard error; Cl: Confidence interval; HR: Hazard ratio

lesions of $1-2$ vs $3-4$ vs. $\geq 5$ did not approach significance. The importance of the number of brain metastases vs. the total tumor volume in predicting OS remains under debate. $[9,25,26]$ We found that the number of brain metastases and total tumor volume were statistically significantly only according to treatment modality arms on univariate analyses. In our study, the median OS was highest in the combined WBRT-GK arm for patients with brain metastases volume $>4 \mathrm{~cm} 3$ ( $\mathrm{p}=0.009)$. Several studies showed that the tumor volume was statistically significantly correlated with the OS. $[2,27,28]$ Total tumor volume should be examined more closely in future studies. In our study, the median survival was the highest for patients with $\geq 5 \mathrm{BM}$ in the combined WBRT-GK arm $(\mathrm{p}=0.014)$. Gamma Knife salvage therapy may be applied with WBRT in patients with $\geq 5$ BM.[29] Considering the survival benefit of the combination of WBRT and SRS, hippocampus sparing-WBRT studies are required to reduce the cognitive effects of WBRT.[30]

In our study, patients who underwent brain metastasectomy had better the median survival than the patents who did not undergo brain metastasectomy, which was statistically significant. The combined WBRT-GK treatment improved the overall survival of the patients who did not undergo brain metastasectomy. The combined WBRT-GK treatment was not related with the median OS in patients who underwent brain metastasectomy. In two trials [31,32], a survival benefit was reported for patients underwent the combined brain metastasectomy+WBRT.

Chemotherapy has a limited role in the treatment of brain metastases. Several studies have reported that some patients might benefit from aggressive therapy, including surgery, radiotherapy and chemotherapy. [33] Kim et al. analyzed retrospectively the outcome of chemotherapy only, upfront whole brain radiotherapy or stereotactic radiosurgery in NSCLC patients with asymptomatic brain metastases. There was no significant difference in OS among three groups, but a subset analysis of 110 patients suggested a potential role of systemic chemotherapy alone or upfront SRS followed by chemotherapy. [34] In another study, a combination of local therapies and systemic chemotherapy shown to increase survival in NSCLC patients with brain metastases.[35] In a multicenter phase II study by Galletta et al. analyzed the association of combination with cisplatin, fotemustine, and whole brain radiotherapy, but this scheme does not represent a therapeutic option for patients with NSCLC.[36] Similar to these reports, we showed that patients with brain metastases from lung cancer had better survival when chemotherapy was used as a treatment option. Since we have a small number of patients groups as a limitation, we look forward to the new reports assessing the efficacy of chemotherapy for brain metastases from lung cancer. 
Similar to other studies, we demonstrated overall survival was better in patients with KPS $\geq 70$ on univariate analysis. [37,6] Ji et al. showed that overall survival was increased in patients with favorable KPS on univariate analysis and multivariate analyses. [38] In our study, OS was increased in patients with favorable KPS, control of the extracranial disease, controlled primary tumor as reported by Gao.[39] Our series also matches with previous reports that have demonstrated improved median OS with better control of the extracranial disease.[13,35] The OS was better in the study of 294 cases with controlled primary tumor, similar to our study.[25] However, another study reported that the OS improved in patients with controlled primary tumor and previous metastasectomy.[40] RPA Class 1 (Class 1, median survival 20 months) was different from the original data because the number of our patients in RPA class 1 was small. In the first RTOG study by Gaspar, the median OS of patients with RPA Class 1 was 7.1 months.[14] In another study, including 445 cases by Gaspar, median OS was 6.2 months for RPA 1, 3.8 months for RPA 2.[41] In the study of 528 cases by Nieder, the RPA class received similar results, but the number of patients in RPA Class 1 was very small.[42] In the study of 110 patients by Lorenzoni et al., median OS was 27.6 months for RPA Class 1, 10.7 months for RPA Class 2, similar to our study.[15] In our multivariate analysis, BS-BM $(p=0.033)$ was a better predicted the survival of BM. Lorenzoni reported that median OS was undefined for BS-BM 3 (55\% at 32 months) and was 13.1 months for BS-BM 2. However, the median OS was 20 months for BS-BM 3, and 12 months for BS-BM 2 in our study.[15] Similar to our multivariate analysis, Villa et al. reported that the median OS improved for BS-BM $(\mathrm{p}<0.001)$. In this prospective study, prognostic indexes as RPA, and BS-BM were prognostically relevant in BM patients similar to in our univariate analysis. [43] In other retrospective study of 335 patients by Ji et al., RPA and BSBM were statistically significant for OS, similar to our study.[38] In the study of 1960 cases with BM by Sperduto, GPA was an appropriate prognostic index.[16] In our study, DS-GPA was not statistically significant for OS, while it was statistically significant in other studies. [15,43,38] Modified Lung-Specific GPA improved the OS of patients with brain metastasis from lung cancer, similar to our study.[17]

\section{Limitations of the Study}

Our study has several limitations. The retrospective nature of this study and the small number of patients are the major limitations.

\section{Conclusion}

In multivariate analysis, we found that control of primary tumor, combined treatment with WBRT-GK, brain metastasectomy and chemotherapy were statistically significant for overall survival of patients with $\mathrm{BM}$. In univariate analysis, prognostic indexes as KPS, RPA class, BS-BM, and Modified Lung-Specific GPA assessed could predict patient prognosis, demonstrating the reliability and clinical relevance of these scores. However, only BS-BM was a better predictor for the survival of patients with $\mathrm{BM}$ according to prognostic score indexes on multivariate analysis. Our data suggest that $\mathrm{BS}-\mathrm{BM}$ is the most appropriate prognostic index.

Peer-review: Externally peer-reviewed.

Conflict of Interest: None declared.

Ethics Committee Approval: Approval from the research ethics board was obtained from Pamukkale University Ethics Committee.

Financial Support: None declared.

Authorship contributions: Concept - H.S., P.B.B.; Design - H.S., P.B.B.; Supervision - H.S., P.B.B.; Funding - None; Materials - H.S., P.B.B.; Data collection and/or processing - H.S., P.B.B.; Data analysis and/or interpretation - H.S., P.B.B.; Literature search - H.S., P.B.B.; Writing - H.S., P.B.B.; Critical review - H.S., P.B.B.

\section{References}

1. Nussbaum ES, Djalilian HR, Cho KH, Hall WA. Brain metastases. Histology, multiplicity, surgery and survival. Cancer 1996;78(8):1781-8.

2. Bhatnagar AK, Flickinger JC, Kondziolka D, Lunsford LD. Stereotactic radio-surgery for four or more intracranial metastases. Int J Radiat Oncol Biol Phys 2006;64(3):898-903.

3. Nayak L, Lee EQ, Wen PY. Epidemiology of brain metastases. Curr Oncol Rep 2012;14(1):48-54.

4. Bradley KA, Mehta MP. Management of brain metastases. Semin Oncol 2004;31(5):693-701.

5. Andrews DW, Scott CB, Sperduto PW, Flanders AE, Gaspar LE, Schell MC, et al. Whole brain radiation therapy with or without stereotactic radiosurgery boost for patients with one to three brain metastases: phase III results of the RTOG 9508 randomised trial. Lancet 2004;363(9422):1665-72.

6. Patchell RA. The management of brain metastases. Cancer Treat Rev 2003;29(6):533-40.

7. Kocher M, Wittig A, Piroth MD, Treuer H, Seegenschmiedt $\mathrm{H}$, Ruge $\mathrm{M}$, et al. Stereotactic radiosurgery 
for treatment of brain metastases. A report of the DEGRO Working Group on Stereotactic Radiotherapy. Strahlenther Onkol 2014;190(6):521-32.

8. Mehta MP, Tsao MN, Whelan TJ, Morris DE, Hayman JA, Flickinger JC, et al. The American Society for Therapeutic Radiology and Oncology (ASTRO) evidence-based review of the role of radiosurgery for brain metastases. Int J Radiat Oncol Biol Phys 2005;63(1):37-46.

9. Sperduto PW, Chao ST, Sneed PK, Luo X, Suh J, Roberge D, et al. Diagnosis-specific prognostic factors, indexes, and treatment outcomes for patients with newly diagnosed brain metastases: a multi-institutional analysis of 4,259 patients. Int J Radiat Oncol Biol Phys 2010;77(3):655-61.

10. Kocher M, Soffietti R, Abacioglu U, Villà S, Fauchon F, Baumert BG, et al. Adjuvant whole-brain radiotherapy versus observation after radiosurgery or surgical resection of one to three cerebral metastases: results of the EORTC 22952-26001 study. J Clin Oncol 2011;29(2):134-41.

11. Chang EL, Wefel JS, Hess KR, Allen PK, Lang FF, Kornguth DG, et al. Neurocognition in patients with brain metastases treated with radiosurgery or radiosurgery plus whole-brain irradiation: a randomised controlled trial. Lancet Oncol 2009;10(11):1037-44.

12. Tsao MN, Lloyd N, Wong RK, Chow E, Rakovitch E, Laperriere $\mathrm{N}$, et al. Whole brain radiotherapy for the treatment of newly diagnosed multiple brain metastases. Cochrane Database Syst Rev 2012;(4):CD003869.

13. Rades D, Janssen S, Bajrovic A, Khoa MT, Veninga T, Schild SE. A matched-pair analysis comparing wholebrain radiotherapy with and without a stereotactic boost for intracerebral control and overall survival in patients with one to three cerebral metastases. Radiat Oncol 2017;12(1):69.

14. Gaspar L, Scott C, Rotman M, Asbell S, Phillips T, Wasserman $\mathrm{T}$, et al. Recursive partitioning analysis (RPA) of prognostic factors in three Radiation Therapy Oncology Group (RTOG) brain metastases trials. Int J Radiat Oncol Biol Phys 1997;37(4):745-51.

15. Lorenzoni J, Devriendt D, Massager N, David P, Ruíz $S$, Vanderlinden B, et al. Radiosurgery for treatment of brain metastases: estimation of patient eligibility using three stratification systems. Int J Radiat Oncol Biol Phys 2004;60(1):218-24.

16. Sperduto PW, Berkey B, Gaspar LE, Mehta M, Curran W. A new prognostic index and comparison to three other indices for patients with brain metastases: an analysis of 1,960 patients in the RTOG database. Int J Radiat Oncol Biol Phys 2008;70(2):510-4.

17. Marcus LP, Marshall D, Hirshman BR, McCutcheon BA, Gonda DD, Koiso T, et al. Cumulative Intracranial Tumor Volume (CITV) Enhances the Prognostic
Value of the Lung-Specific Graded Prognostic Assessment (GPA) Model. Neurosurgery 2016;79(2):246-52.

18. Rades D, Janssen S, Dziggel L, Blanck O, Bajrovic A, Veninga $\mathrm{T}$, et al. A matched-pair study comparing whole brain irradiation alone to radiosurgery or fractionated stereotactic radiotherapy alone in patients irradiated for up to three brain metastases. BMC Cancer 2017;17:30.

19. Yomo S, Hayashi M. The efficacy and limitations of stereotactic radiosurgery as a salvage treatment after failed whole brain radiotherapy for brain metastases. J Neurooncol 2013;113(3):459-65.

20. Soon YY, Tham IW, Lim KH, Koh WY, Lu JJ. Surgery or radiosurgery plus whole brain radiotherapy versus surgery or radiosurgery alone for brain metastases. Cochrane Database Syst Rev 2014;(3):CD009454.

21. Kaplan EL, Meier P. Nonparametric estimation from incomplete observations. J Am Stat Assoc 1958;53:457-81.

22. Wegner RE, Olson AC, Kondziolka D, Niranjan A, Lundsford LD, Flickinger JC. Stereotactic radiosurgery for patients with brain metastases from small cell lung cancer. Int J Radiat Oncol Biol Phys 2011;81(3):e21-7.

23. Kevin S, Loeffler JS. The changing landscape of wholebrain radiation therapy invited commentary. JAMA Oncol 2015;1(4):464-5.

24. Bowden G, Kano H, Caparosa E, Park SH, Niranjan A, Flickinger J, et al. Gamma knife radiosurgery for the management of cerebral metastases from non-small cell lung cancer. J Neurosurg 2015;122(4):766-72.

25. Ebner DK, Gorovets D, Rava P, Cielo D, Kinsella TJ, DiPetrillo TA, et al. Patients with Long-Term Control of Systemic Disease Are a Favorable Prognostic Group for Treatment of Brain Metastases with Stereotactic Radiosurgery Alone. World Neurosurg 2017;98:266-72.

26. Miller JA, Kotecha R, Ahluwalia MS, Mohammadi AM, Chao ST, Barnett GH, et al. Overall survival and the response to radiotherapy among molecular subtypes of breast cancer brain metastases treated with targeted therapies. Cancer 2017;123(12):2283-93.

27. Likhacheva A, Pinnix CC, Parikh NR, Allen PK, McAleer MF, Chiu MS, et al. Predictors of survival in contemporary practice after initial radiosurgery for brain metastases. Int J Radiat Oncol Biol Phys 2013;85(3):656-61.

28. Baschnagel AM, Meyer KD, Chen PY, Krauss DJ, Olson RE, Pieper DR, et al. Tumor volume as a predictor of survival and local control in patients with brain metastases treated with Gamma Knife surgery. J Neurosurg 2013;119(5):1139-44.

29. Sengöz M, Kabalay IA, Tezcanlı E, Peker S, Pamir N. Treatment of brainstem metastases with gamma-knife radiosurgery. J Neurooncol 2013;113(1):33-8. 
30. Gondi V, Pugh SL, Tome WA, Caine C, Corn B, Kanner A, et al. Preservation of memory with conformal avoidance of the hippocampal neural stem-cell compartment during whole-brain radiotherapy for brain metastases (RTOG 0933): a phase II multi-institutional trial. J Clin Oncol 2014;32(34):3810-6.

31. Patchell RA, Tibbs PA, Walsh JW, Dempsey RJ, Maruyama Y, Kryscio RJ, et al. A randomized trial of surgery in the treatment of single metastases to the brain. N Engl J Med 1990;322(8):494-500.

32. Vecht CJ, Haaxma-Reiche H, Noordijk EM, Padberg GW, Voormolen JH, Hoekstra FH, et al. Treatment of single brain metastasis: radiotherapy alone or combined with neurosurgery? Ann Neurol 1993;33(6):583-90.

33. Harita S, Mizuta A, Kuyama S, Kikuchi T. Longterm survival following concurrent chemoradiotherapy in patients with non-small cell lung cancer with concomitant brain metastases only. Int J Clin Oncol 2005;10(1):63-8.

34. Kim KH, Lee J, Lee JI, Nam DH, Kong DS, Ahn YC, et al. Can upfront systemic chemotherapy replace stereotactic radiosurgery or whole brain radiotherapy in the treatment of non-small cell lung cancer patients with asymptomatic brain metastases? Lung Cancer 2010;68(2):258-63.

35. Kim DY, Lee KW, Yun T, Kim DW, Kim TY, Heo DS, et al. Efficacy of platinum-based chemotherapy after cranial radiation in patients with brain metastasis from non-small cell lung cancer. Oncol Rep 2005;14(1):207-11.

36. Galetta D, Gebbia V, Silvestris N, Ferraù F, Carrozza F, Cigolari S, et al. Cisplatin, fotemustine and whole-brain radiotherapy in non-small cell lung cancer patients with asymptomatic brain metastases: a multicenter phase II study of the Gruppo Oncologico Italia Meridionale (GOIM 2603). Lung Cancer 2011;72(1):59-63.

37. Owen S, Souhami L. The management of brain metastases in non-small cell lung cancer. Front Oncol 2014;4:248.

38. Ji X, Zhuang Y, Yin X, Zhan Q, Zhou X, Liang X. Survival time following resection of intracranial metastases from NSCLC-development and validation of a novel nomogram. BMC Cancer 2017;17(1):774.

39. Gao HX, Huang SG, Du JF, Zhang XC, Jiang N, Kang WX, et al. Comparison of Prognostic Indices in NSCLC Patients with Brain Metastases after Radiosurgery. Int J Biol Sci 2018;14(14):2065-72.

40. Harris KB, Corbett MR, Mascarenhas H, Lee KS, Arastu H, Leinweber C, et al. A Single-Institution Analysis of 126 Patients Treated with Stereotactic Radiosurgery for Brain Metastases. Front Oncol 2017;7:90.

41. Gaspar LE, Scott C, Murray K, Curran W. Validation of the RTOG recursive partitioning analysis (RPA) classification for brain metastases. Int J Radiat Oncol Biol Phys 2000;47(4):1001-6.

42. Nieder C, Nestle U, Motaref B, Walter K, Niewald M, Schnabel K. Prognostic factors in brain metastases: should patients be selected for aggressive treatment according to recursive partitioning analysis (RPA) classes? Int J Radiat Oncol Biol Phys 2000;46(2):297-302.

43. Villà S, Weber DC, Moretones C, Mañes A, Combescure C, Jové J, et al. Validation of the new Graded Prognostic Assessment scale for brain metastases: a multicenter prospective study. Radiat Oncol 2011;6:23. 